\title{
Somatic KIT Gene Mutation
}

National Cancer Institute

\section{Source}

National Cancer Institute. Somatic KIT Gene Mutation. NCI Thesaurus. Code C148107.

A change in the nucleotide sequence of the KIT gene that originated in non-germline cells. 